Article

\title{
Enhancing Memorable Experiences, Tourist Satisfaction, and Revisit Intention through Smart Tourism Technologies
}

\author{
Zabih-Allah Torabi ${ }^{1, *(\mathbb{D}, \text { Ali Asghar Shalbafian }}{ }^{2}$, Zaheer Allam ${ }^{3,4}\left(\mathbb{D}\right.$, Zahed Ghaderi $^{5}$, Beniamino Murgante ${ }^{6}(\mathbb{D}$ \\ and Amir Reza Khavarian-Garmsir ${ }^{7}$ (1)
}

check for

updates

Citation: Torabi, Z.-A.; Shalbafian,

A.A.; Allam, Z.; Ghaderi, Z.;

Murgante, B.; Khavarian-Garmsir,

A.R. Enhancing Memorable

Experiences, Tourist Satisfaction,

and Revisit Intention through Smart

Tourism Technologies. Sustainability

2022, 14, 2721. https://doi.org/

$10.3390 /$ su14052721

Academic Editor: Mark

Anthony Camilleri

Received: 24 January 2022

Accepted: 21 February 2022

Published: 25 February 2022

Publisher's Note: MDPI stays neutral with regard to jurisdictional claims in published maps and institutional affiliations.

Copyright: (C) 2022 by the authors Licensee MDPI, Basel, Switzerland. This article is an open access article distributed under the terms and conditions of the Creative Commons Attribution (CC BY) license (https:// creativecommons.org/licenses/by/ $4.0 /)$.
1 Department of Studies in Geography, Tarbiat Modares University, Tehran 14117-13116, Iran

2 Department of Tourism, Semnan University, Semnan 35131-19111, Iran; ashalbafian@semnan.ac.ir

3 Chaire Entrepreneuriat Territoire Innovation (ETI), IAE Paris-Sorbonne Business School, Université Paris 1 Panthéon-Sorbonne, 75013 Paris, France; zaheerallam@gmail.com

4 Live+Smart Research Laboratory, School of Architecture and Built Environment, Deakin University, Geelong, VIC 3220, Australia

5 Department of Tourism, College of Arts and Social Science, Sultan Qaboos University, Muscat 123, Oman; z.ghaderi@squ.edu.om

6 School of Engineering, University of Basilicata, 10 Viale dell'Ateneo Lucano, 85100 Potenza, Italy; beniamino.murgante@unibas.it

7 Department of Geography and Urban Planning, Faculty of Geographical Sciences and Planning, University of Isfahan, Isfahan 81746-73441, Iran; a.khavarian@geo.ui.ac.ir

* Correspondence: zabih.torabi@modares.ac.ir

\begin{abstract}
Global connectivity facilitated tourism and redefined economic landscapes, highlight an interest in better understanding tourism retention factors. Today, in view of the global COVID-19 pandemic, this is made even more important as the world prepares to lift lockdown restrictions and to re-engage in cross border circulation; reiterating needs to understand tourism satisfaction and revisit intentions. This study thus sheds light on the predictors of tourists' intention to the explorative and exploitative use of Smart Tourism Technologies (STTs) and memorable experiences in tourism destinations via an integrated model and a self-administered questionnaire-distributed among domestic tourists visiting Tehran-employing the Theory of Planned Behavior (TPB). The results indicated that tourists' attitudes, subjective norms, and perceived behavioral control toward STTs had significant positive impacts on their explorative and exploitative intentions. Furthermore, tourists explorative/exploitative intention and perceived behavioral control exercised significant, positive effects on their memorable experiences. Finally, the results demonstrate that tourists' memorable experiences significantly influence their satisfaction and intention to revisit smart destinations. This study expands existing literature by exploring a new model for enhancing memorable experiences and revisit intention using STTs, and presents findings applicable to the city of Tehran, while adopting a model which can be replicated in other geographies looking at better understanding its tourism landscape. Finally, the results in this study can be helpful for both researchers and policy makers in their quest to rejuvenate local post-pandemic economies via tourism measures.
\end{abstract}

Keywords: Theory of Planned Behavior; Smart Tourism Technologies; tourist satisfaction; memorable experiences; revisit intention; COVID-19

\section{Introduction}

The use of Smart Tourism Technologies (STTs) in travel plans has surged over the past decade [1] with a majority of tourists selecting smart destinations for their trips [2]. In fact, the use of STTs is no longer regarded as a secondary requirement but as a primary, critical component that will gain even more traction after the emergence of COVID-19, as economies prepare for easing lockdown restrictions [3]. For example, STTs can be utilized by tourists to gain information about the best routes, traffic status, air pollution, quality of 
restaurants and hotels, and with advanced technologies such as Augmented Realities (AR) and Gaming Sightseeing, tourists have the opportunity to virtually sample different products that different destinations can offer [4]. Such technologies also improve trip flexibility in destinations because tourists can instantly change their routes, their residential areas and/or transportation type $[4,5]$. Thus, in comparison with traditional tourism, tourists can be engaged in a more unique and interactive way by using STTs [6]. An interesting emerging theme relevant to this study is that of memorable tourism experiences (MTE), relating to how tourists perceive their trip in a given locality. This is often equated to how tourists experience the authenticity and aesthetic appeal via: (1) the theme of the experience, (2) positive cues, (3) eliminating negative communication, (4) mix in memorabilia, and (5) accentuating the use of all the five senses [7,8]. With the quality of using STTs for memorable experiences, tourists' satisfaction and intention to revisit are tightly interrelated with their behaviors; hence, TPB can be utilized to predict and explore tourists behavior [7-10]. This theory has been exploited in a wide range of tourism-related studies to analyze the behaviors of tourists using smart technologies [11,12], and it is anticipated that it will become even more popular with new realities that have been prompted by the COVID-19 pandemic, where human behaviors are expected to change, to align with the new normal.

To test the research hypotheses in the current study, principles of the Theory of Planned Behavior (TPB) theory that was proposed and advanced by Ajzen were adopted $[9,13]$. In his work, Ajzen used the theory to predict the likelihood of the occurrence of a particular behavior provided that the individual has the intention to do the behavior [14]. As a result, it has been observed that this theory pays special attention to social factors that may shape the behavior(s) of an individual $[15,16]$. With this theory, intention, and behavior are predicted using three factors, namely; attitude toward behavior, subjective norms, and perceived behavioral control $[9,17]$.

Prior studies have indicated the impact of STTs on creating new experience tourism and shift in the meaning of travel [11,18-22]. Ghaderi et al. [11] concluded that tourists' attitudes, subjective norms, and perceived behavioral control toward smart phones can result in unique local experiences. Therefore, in the current study, attitude, subjective norms, and perceived behavioral control toward STTs were used as predictors of the intention toward explorative and exploitative use of STTs and memorable experiences. Further, this study not that the intention toward explorative use of STTs majorly entails unstructured tasks in planning travels which require search, risk taking, exploration, and innovation and take time to be learned and adapted [23,24]. In contrast, the intention toward the exploitative use of STTs is often reminiscent of some particular expressions such as refinement, efficiency, and execution. Indeed, the intention toward the exploitative use of STTs connotes better use of available resources and processes in travel planning [1,25].

Previous research has further demonstrated that memorable experiences in smart destinations can promote tourists' satisfaction and revisit intention [22,26-28]. This was affirmed by Kim [29] who after carefully studying five cities discovered that memorable experience enhances tourists' satisfaction and revisit intention with a high coefficient. According to the available literature, promoting tourists' revisit intention on a specific destination does not only encourages them to visit that destination again, but also makes them persuade others to visit it $[22,30,31]$, thereby helping in the reduction of the costs associated with attracting new tourists [32], declines tourists' sensitivity to variations and prices, leads to higher gains connected with customer longevity value [33], enhances the likelihood of positive performance stemming from higher predictability, and creates barriers for new rivals [34,35]. Although STT is typically used to achieve memorable experiences, a limited number of studies have been conducted on this subject. To the best of our knowledge, there is no thorough study that has been published investigating the role of increasing memorable experiences in tourists' satisfaction and revisit intention through using STTs. Most of the previous studies have majorly focused on describing STTs. 
In fact, this stream of research has supported the various types of technologies used in travel and tourism and their attributes. A further examination of the underlying mechanism with which travelers use these STTs can greatly advance our understanding of the role that these technologies play in travel planning activities to achieve satisfaction and revisit intention. In this study, we make use of an exploration and exploitation framework, first adopted in the context of organizational learning and later extended to information technology use, to inspect the way that STTs are used in travel planning.

To address the existing gap in the literature, and capture the new developments prompted by dynamics such as COVID-19 and emerging health protocols, especially in regard to human interactions, the present study explored an integrated model describing the quality of memorable experiences and its impact on tourists' satisfaction and revisit intention via the use of STTs. To this end, Tehran was used as the case study for the target tourist destination in the study given that a large number of both domestic and foreign tourists visit the city on a daily basis and it enjoys better STTs infrastructure in comparison with other cities within the country [36,37]. As a result, tourists in this city have more opportunities to utilize STTs, and information can be sourced from the increasing use of Internet of Things in urban milieus, and complement the rich and unique cultural fabric that attracts tourism.

Considering the aim of the study, the following research question was formulated: How do tourists' attitudes, subjective norms, perceived behavioral control, and intention toward explorative and exploitative use of STTs influence their memorable experiences, satisfaction, and revisit intention smart destinations? By answering this question, this study intends to provide destination marketers with useful suggestions for future digitization of destinations. The chosen case study is the city of Tehran, and results offer a perspective on how similar research can be conducted in other geographies, while underlining avenues for future research.

\section{Literature and Research Hypotheses}

The concept of smartness was brought up in the 1990s and since then, it has received considerable attention amongst people from diverse backgrounds $[38,39]$. The smartness of a city entails the degree with which it utilizes information and communication technology to enhance different aspects [40]. In fact, a smart city could be viewed as one which integrates the daily routines with information and communication technologies (e.g., artificial intelligence, cloud computing, IoT, and mobile communications) [22]. The primary purpose of smart tourism is to create a link between the visitor and the destination for a one-way response to cater to specific needs [41]. A smart tourism destination is known for its high level of innovation and facilitation using technology [42]. Similar to cities that exploit various smart technologies to promote the residents' life quality, tourist destinations have welcomed smart technologies to improve the tourists' experience and the destination's competitiveness $[6,43]$. In the current study, STTs included ubiquitous computing and Internet of Things (IoT), cloud computing, ubiquitous connectivity through $\mathrm{Wi}-\mathrm{Fi}$, near field communication (NFC), and radio-frequency identification (RFID), sensors, smartphones, mobile connected devices, beacons, virtual reality (VR), augmented reality (AR), mobile apps, integrated payment methods, smart cards, and social networks sites, etc. [1,44]. Tourists are attracted to a wide array of smart technologies to gain more accurate, richer, more comprehensive, and more personal information to promote their experiences during the trip [1]. Gathering such information helps them collect enough mobility and motivation to enrich their travel experience in tourist areas [22].

Ghaderi et al. [11] argues that tourists utilize smart technologies in different ways. Indeed, the type and quality of using such technologies (explorative versus exploitative use) create disparate experiences for tourists. In this regard, Koo et al. [25] believes that attitudes, norms, and perceived behavioral control are able to determine people's behavioral intentions or change their behaviors. As a result, this study adopted the TPB to explore the impact of behavioral variables on the quality of using STTs, memorable experience, 
and intention to revisit. This theory primarily focuses on social factors that shape behavior. Accordingly, the intention to pursue a particular type of behavior is inspired by three factors, namely attitude toward that behavior, subjective norms, and perceived behavioral control [11]. TPB, proposed by the Ajzen, is based on the theory of rational action. It should be mentioned that in the TPB, behavioral intentions are considered before they are formed. It has been argued that the greater the intention of an individual to take concrete action, the more success can be expected $[9,45]$. Intentions are the silent execution of beliefs or information and determine whether or not the intention to perform a particular behavior will lead to a particular outcome. Indeed, intentions can be changed over time [46].

Attitude toward behaviors indicate psychological evaluations such as good/bad, useful/harmful, pleasant/unpleasant, and lovely/disgusting [2,9]. In this study, tourists' attitudes toward STTs refers to individuals' assessment of the (in)appropriateness of using STTs. According to TPB, many of individuals' behavioral decisions are based on voluntary activities; thus, people's behavioral intention is a function of their attitudes $[47,48]$. Individuals with a positive attitude toward STTs commonly try to utilize it to plan their trips [49]; hence, justifying the arguments by Ghaderi et al. (2019) that attitude toward STTs influences the way such technologies are used. Huang et al. [1] argues that tourists who have developed positive attitudes towards smart technologies use them to search for, and discover new tourist attractions, sites and activities. In a similar vein, Koo et al. [25] concluded that attitude toward STTs profoundly influences people's selection and comparison of available activities and attractions. In the current study, it is assumed that tourists' attitudes toward STTs may predict their behavioral intention, including intention toward explorative and exploitative use of STTs. More precisely, it is hypothesized that developing more positive attitude toward STTs will yield stronger intention toward their explorative and exploitative use [50-52]. In this regard, Ghaderi et al. [11] found that, in general, tourists' positive attitude toward smart phones raises their intention toward travelling to smart destinations. Quintal et al. [53] and H. Han et al. [2] further contended that tourists' attitudes have the strongest impact on their behavioral intention. Other correlational studies have displayed that tourists' attitudes are a significant predictor of their behavioral intention [10,15,54-56]. This reasoning leads to the following hypotheses:

Hypothesis 1 (H1). Tourists' attitudes have a significant, positive effect on their intention toward explorative use of STTs.

Hypothesis 2 (H2). Tourists' attitudes have a significant, positive effect on their intention toward exploitative use of STTS.

An average person is influenced by various people in his or her life $[9,17]$. Thus, individuals surrounding a person (e.g., family members, religious leaders, political leaders, etc.) affect his/her beliefs and behaviors [11]. Some people may urge that the person in question must behave in a particular way, while others may insist that he/she should refrain from such behavior. In such a situation, the person is obliged to strike a balance between contradictory pressures from different opposing forces $[10,11,46]$. His/her behavior is more likely to be influenced by people with a more profound influence. In other words, the person's intention to accept a specific type of behavior is potentially influenced by people who are closer to him/her. Consequently, subjective norms may be regarded as a valid predictor of behavioral intention [57]. On this, there are numerous studies demonstrating how tourists' subjective norms influence their behavioral intention $[2,11,15,47]$. In the current study, tourists' subjective norms toward STTs are utilized to predict their behavioral intention, including their explorative and exploitative use of STTs. Indeed, it is hypothesized that social pressures, which encourage or discourage people to use STTs, may affect the way they utilize STT (explorative and exploitative use). This reasoning leads to the following hypotheses: 
Hypothesis 3 (H3). Tourists' subjective norms have a significant, positive effect on their intention toward exploitative use of STTs.

Hypothesis 4 (H4). Tourists' subjective norms have a significant, positive effect on their intention toward explorative use of STTs.

Perceived behavioral control entails the degree to which people feel conducting a particular behavior is under their voluntary control $[9,16,48]$. It is influenced by control beliefs and perceived power [15,47]. The former has to do with factors that may facilitate or impede individuals' performance of a behavior, whereas the latter entails people's estimate of the extent to which they can control factors affecting their performance $[9,17]$. Strong control beliefs about the presence of factors facilitating a particular behavior strengthen individuals' perceived control $[2,47,54]$. Conversely, weak control beliefs will undermine people's perceived control discouraging them from adopting the behavior [9]. People's perceptions may depend on their previous experiences, prediction of future events, and attitudes developed under the influence of surrounding norms [17,45]. Following the premises of TPB, perceived behavioral control shapes people's behaviors in two ways: (i) by influencing behavior intention, and (ii) directly predicting behavior [9]. Prior correlational studies have attested to the power of tourists' perceived behavioral control in predicting their behavioral intention and decision $[2,11,13,16,17,46,54,55]$. In the present study, it is assumed that perceived behavioral control toward using smart technologies can affect tourists' intention toward explorative and exploitative use of STTs and memorable experience. In previous research, perceived behavioral control has been measured through the following variables: (1) enough resources; (2) enough time; (3) foreseeable opportunities; (4) recommendation to others; and (5) certainty in using STTs. Thus, the following hypotheses are proposed:

Hypothesis 5 (H5). Tourists' perceived behavioral control has a significant, positive effect on their intention toward explorative use of STTs.

Hypothesis 6 (H6). Tourists' perceived behavioral control has a significant, positive effect on their intention toward exploitative use of STTs.

Hypothesis 7 (H7). Tourists' perceived behavioral control has a significant, positive effect on their memorable experiences.

Behavioral intention refers to a person's willingness to perform a particular behavior [9]. In the present research, behavioral intention has to do with the intention toward explorative and exploitative use of STTs in travel planning. The notions of exploration and exploitation were initially proposed in organizational learning and subsequently extended to other subjects $[23,58]$. Koo et al. [25] opines that exploration has to do with concepts such as searching, discovering, and testing new options. In fact, exploration is intended to solve old problems by the use of innovations. Exploration includes discovering new skills and resources, testing customer definitions instead of accepting customer needs and participating in activities that can introduce new ideas. In other words, exploration is characterized by search, experimentation, risk, and innovation [59]. Exploration can therefore lead to new results and innovative solutions to problems. Exploration challenges existing ideas with innovative and entrepreneurial concepts, while the topic of exploitation primarily focuses on the reconsideration and expansion of existing skills and abilities [24]. Exploitation is thus the extension of old rules that describe a set of activities to improve operational efficiency (for example, by increasing standardization, tightening process control, and reducing manual intervention) [25]. Exploitation thus develops existing knowledge through the use of predetermined procedures, technologies, and solutions. Exploitation includes activities such as refinement, production, productivity, selection, and execution [1]. The distinction between exploitation and exploration is briefly defined by March [60] as the difference between 'exploration of new possibilities' and 'exploitation of old principles and rules.' The use of existing abilities often leads to discovering new abilities because 
exploration and exploitation refer to general behaviors in organizational learning or knowledge management. Huang et al. [1] states that some tourists who have not taken any trip yet and are hesitating about their destination utilize STTs to explore new attractions and activities. Similarly, in the current study, the intention to explore encompasses searching for new attractions and activities in smart destinations via using STTs. Exploitative use of STT, on the other hand, entails utilizing and improving skills that are already known, hence being mainly concerned with choosing from among available options and reusing current procedures [61]. Thus, in this study, exploitative use of STTs refers to evaluating alternatives and booking travel products. Indeed, exploitative use is defined as improving the efficiency of existing activities and standards of controlling processes to fulfill tasks in travel planning. Huang et al. [1] emphasized that explorative and exploitative use of STTs positively influences travel experience. Accordingly, it is hypothesized that tourists explorative and exploitative use of STTs in smart destinations impacts their memorable experiences. This reasoning leads to the following hypotheses:

Hypothesis 8 (H8). Tourists' explorative use of STTs has a significant, positive influence on their memorable experiences.

Hypothesis 9 (H9). Tourists' exploitative use of STTs has a significant, positive influence on their memorable experiences.

While visiting special destinations, tourists would like to engage in unique and memorable experiences [62,63]. Moreover, to gain competitive advantage in the free market, tourist destinations should offer memorable experiences [21], which constitute an accumulation of all the tourists' experiences during the trip [64]. In this study, memorable experience entails a pleasant and unforgettable experience gained through using STTs. Wang et al. [20] believes that tourists' interest in broadening their memorable experiences via using STTs is on the rise. Using STTs makes it possible for tourists to gain unique information during travel [18,34]. For example, tourists can collect valuable information about traditional bazaars (e.g., history, the course of events, location in relation to other historical sites, etc.) by the use of smart phones $[11,20,28,65]$. They can also locate residential areas and restaurants instantly and explore other people's opinions about their target locations. As a result, STTs can improve their travel experience by creating numerous opportunities that would be limited, or costly if they embraced the traditional approaches $[1,25,28]$. In light of the significance of memorable experiences in smart tourist destinations, the present study aims to examine two consequences of memorable experiences, namely, satisfaction and revisit intention. Running a positive evaluation of experiences during a trip may enhance tourists' satisfaction and revisit intention. Chen and Rahman [66], collecting data from American tourists who had visited several cultural centers during the past five years leading to the study, concluded that tourists' memorable experiences affect their revisit intention and intention to recommend. Jeong and Shin [22] also showed that gaining memorable experiences through using STTs enhances tourists' satisfaction and revisit intention. In another study, Kim [29], gathering data from tourists in Taiwan who had come from China, Hong Kong, Macao, Japan, South Korea, and the United States, concluded that memorable experiences have a positive impact on tourists' satisfaction and revisit intention. Based on the findings of previous studies, the following hypotheses are proposed:

Hypothesis 10 (H10). Tourists' memorable experiences have a significant, positive influence on their satisfaction.

Hypothesis 11 (H11). Tourists' memorable experiences have a significant, positive influence on their revisit intention.

Tourists' satisfaction encompasses a collection of their psychological status originating from their experience gained through participation in tourism activities [22,32]. This then is viewed as a critical factor in determining tourists' revisit intention of a particular destina- 
tion [67]. Tourists are more likely to revisit a destination if they are satisfied with it [68]. On the contrary, when they are not satisfied with their travel experience, they are less likely to revisit the destination and recommend it to others [27,29]. Thus, to function as successful tourist attractions, smart destinations should create satisfying experiences for tourists since satisfaction with smart destinations is a vital factor in establishing long-term relationships between tourists and destinations $[6,19,22]$.

There are a large number of studies exploring the impact of tourists' satisfaction on their intention to revisit a destination. Jeong and Shin [22], for instance, found that tourists' satisfaction with smart destinations functions as a predictor of their revisit intention. In the current study, tourists' satisfaction with smart destinations is regarded as a variable mediating the relationship between memorable experiences and revisit intention [22]. Prior research findings further demonstrate that tourists' satisfaction is a significant predictor of their revisit intention $[19,22,26,29,32,69]$. In this study, tourists' satisfaction with smart destinations was gauged via the following variables: (1) satisfaction with STTs; (2) fulfillment of tourists' STT-related expectations; and (3) the quality of STTs during travel.

Hypothesis 12 (H12). Tourists' satisfaction has a significant, positive influence on their revisit intention.

In the present study, the smart destination's revisit intention was used as the endogenous variable being predicted by seven variables, namely, attitude, subjective norms, perceived behavioral control, intention toward explorative use, intention toward exploitative use, memorable experiences, and satisfaction. This hypothesized model demonstrates the process of enhancing memorable experiences via STTs and tourists' revisit intention to smart destinations (Figure 1). The research model is designed in three levels. It deals with the hypotheses $\mathrm{H} 1, \mathrm{H} 2, \mathrm{H} 3, \mathrm{H} 4, \mathrm{H} 5$, and $\mathrm{H} 6$; and the impacts of tourists' attitudes, subjective norms, and perceived behavioral control in their intention toward explorative/exploitative use of STTs are analyzed. Besides, the link between perceived behavioral control and memorable experiences is tested based the hypothesis H7. To address the hypotheses H8 and H9, we analyze the influence of STTs' explorative/exploitative use in memorable experiences in the second level. The third level focuses on H10, H11, and H12 hypotheses and investigates the role of memorable experiences in increasing tourists' satisfaction and revisit intention. Moreover, it focuses on the influence of tourists' satisfaction in revisit intention.

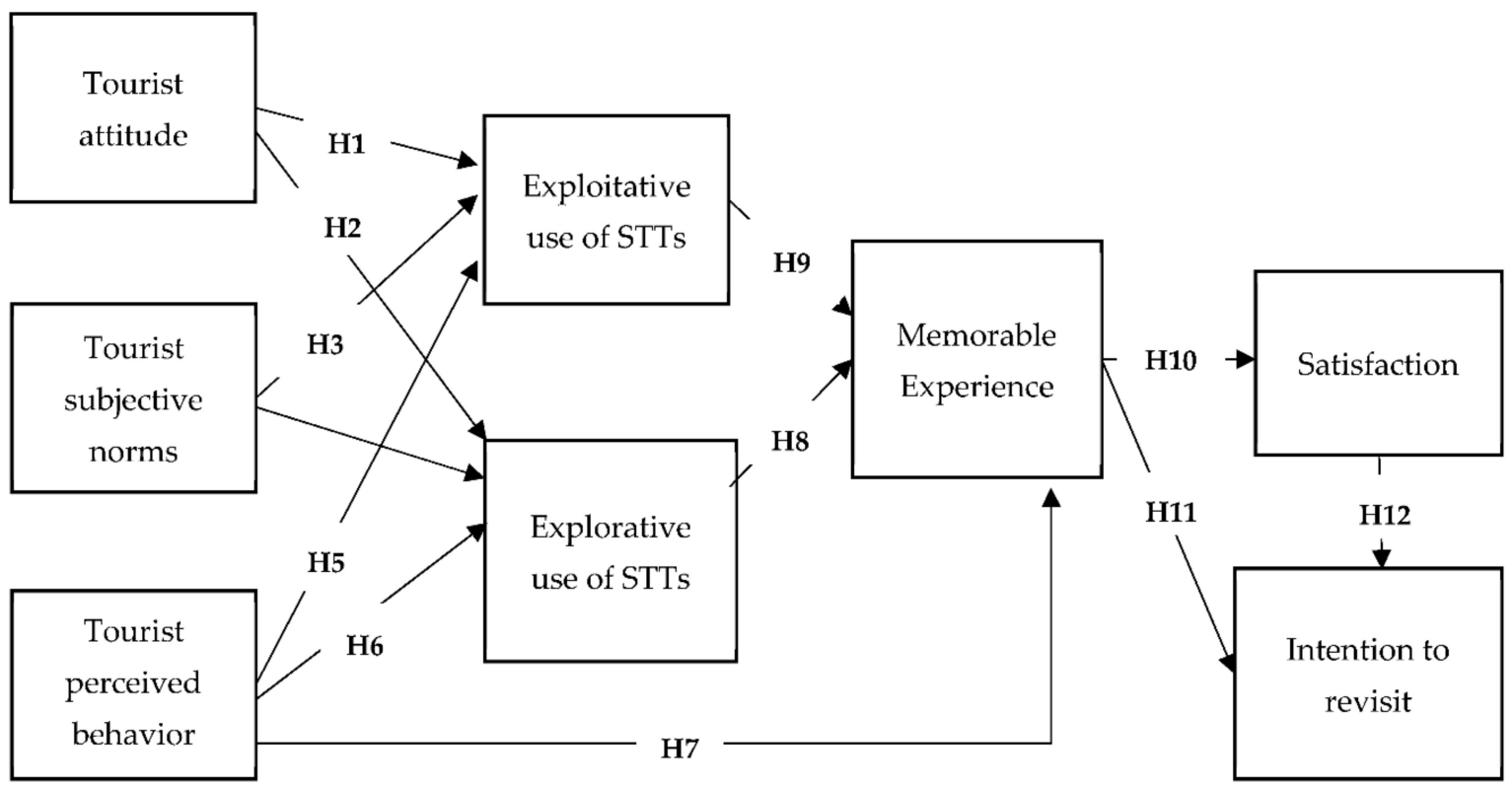

Figure 1. Research model. 


\section{Methodology}

\subsection{Context of Tehran}

Tehran is the biggest city in Iran with a population of almost 9 million people, thus, it is home to around $11 \%$ of Iran's total population. Due to its diversity and dynamism, the city has over the years become a popular tourist destination not only for international visitors, but also for locals. It has a collection of famous historical-cultural tourist attractions, most of which belong to Qajar dynasty. According to the latest report of the Statistical Center of Iran, approximately 3.5 million domestic tourists visited Tehran in the spring of 2016 [70].

Despite various limitations, internet use has been on the rise in Iran over recent years. In January 2020, 58.2 million internet users were identified in the country, indicating a rise of $11 \%$ in comparison to the same index in 2019. This growth rate is higher than the average global rate of $7 \%$. Moreover, following the 2020 report, the influence rate of the internet was found to be $70 \%$ and the number of mobile connections was equivalent to $152 \%$ of the total population [71]. In addition to mobile and internet penetration, Tehran has been rapidly becoming a smart city, with most of the citizens' and tourists' activities being carried out by the use of smart technologies. As a result, the Internet usage rate in Tehran is now above $113 \%$ following the robust internet infrastructure including in all the roads of the city that are supported by $4 \mathrm{G}$ and $3 \mathrm{G}$ internet. Furthermore, recent years have witnessed a significant growth in the number of service providing applications in Tehran; thus, most of the citizens and tourists fulfill their needs using smart technologies [71].

\subsection{Questionnaire Development}

The measurement scales were designed in light of findings of previous research as well as the special features of the present study. Table 1 displays the corresponding information.

Table 1. Variables and measures used in this study to test the research hypotheses.

\begin{tabular}{|c|c|c|}
\hline Variable & Measure & Reference \\
\hline \multirow{4}{*}{ Tourist attitude } & I expect that tourist destinations use STTs. & \multirow{4}{*}[2,11,53]{} \\
\hline & STTs helps me deviate from routine activities in my travel. & \\
\hline & The presence of STTs infrastructure affects my attitude toward visiting the destination. & \\
\hline & STT helps me gain unique experiences. & \\
\hline \multirow{3}{*}{$\begin{array}{c}\text { Tourist } \\
\text { perceived } \\
\text { behavior control }\end{array}$} & I utilize STTs in my travels to gain new experiences and recommend it to others. & \multirow{3}{*}[2,11,53]{} \\
\hline & I am sure I can use STTs during my travel if I want to. & \\
\hline & I have enough resources, time, and opportunity to use STTs during my travel. & \\
\hline \multirow{3}{*}{$\begin{array}{l}\text { Tourist subjec- } \\
\text { tive norms }\end{array}$} & People who I trust expect me to use STT during my travel to gain unique experiences. & \multirow{3}{*}[9,11,13,47]{} \\
\hline & My family/friends believe that I should use STTs during my travel to gain unique experiences. & \\
\hline & Some people argue that I should use STTs during my travel to gain unique experiences. & \\
\hline \multirow{3}{*}{$\begin{array}{l}\text { Exploitative use } \\
\text { of STTs }\end{array}$} & $\begin{array}{l}\text { I intend to use my smart phone applications in my future travel to compare and select smart } \\
\text { facilities and infrastructure (e.g., ticket sellers, lodges, and dining). }\end{array}$ & \multirow{3}{*}[23,24,58]{} \\
\hline & $\begin{array}{l}\text { I intend to use web-based technologies (e.g., personal weblogs, websites specialized in tourism, } \\
\text { etc.) in my future travel to compare and select smart facilities and infrastructure. }\end{array}$ & \\
\hline & $\begin{array}{l}\text { I intend to use social networks in my future travel to compare } \\
\text { and select smart facilities and infrastructure. }\end{array}$ & \\
\hline \multirow{3}{*}{ explorative use } & $\begin{array}{l}\text { I intend to use smart phone applications (e.g., location-based apps as well as apps used for } \\
\text { booking tickets and hotels, checking traffic status/pollution, etc.) to explore smart attractions } \\
\text { and activities in the destination. }\end{array}$ & \multirow{3}{*}[23,24,58]{} \\
\hline & I intend to use social networks to explore smart attractions and activities in the destination. & \\
\hline & I intend to use web-based technologies smart attractions and activities in the destination. & \\
\hline \multirow{3}{*}{$\begin{array}{l}\text { Participation in } \\
\text { memorable } \\
\text { experiences }\end{array}$} & Smart technology applications create exciting memories (memorable experiences) for me. & \multirow{3}{*}[18,22,29,34,62,63,68]{} \\
\hline & Smart technology applications make my travel pleasant through creating unique experiences. & \\
\hline & Smart technology applications create more unforgettable experiences during my travel. & \\
\hline
\end{tabular}


Table 1. Cont.

\begin{tabular}{ccc}
\hline Variable & Measure & Reference \\
\hline \multirow{3}{*}{ Satisfaction } & The quality of STTs can enhance my satisfaction with the destination. & \\
\cline { 2 - 2 } & Destinations that offers STTs beyond my expectations make my travel more pleasant. & {$[1,13,19,22,27,29,32,33,67]$} \\
\cline { 2 - 2 } Revisit intention & Gaining unique experiences via STTs is one of my ideals and makes me happy. \\
\cline { 2 - 3 } & In future, I will travel to destinations that offer unique experiences via STTs. & I recommend destinations that use unique STTs to my family and friends. \\
\cline { 2 - 2 } & I share my memorable experiences gained via STTs with others. \\
\hline
\end{tabular}

Tourists' attitude, subjective norms, perceived behavioral control, intention toward explorative and exploitative use of STTs, participation in memorable experiences, satisfaction, and revisit intention were gauged using a 5-point Likert scale with anchors ranging from strongly disagree (1) to strongly agree (5).

\subsection{Data Collection Procedure}

A quantitative approach was adopted to assess the proposed model. The population included domestic tourists visiting Tehran in May 2020. Since the number of tourists was not clear beforehand, convenience sampling was used for data collection. The questionnaires were distributed among tourists by proceeding to popular tourist attractions (Tehran's Grand Bazaar, Abbas Abad Recreational and Cultural Complex, Sa'dabad Complex, and museums across the city) in the morning and evening. Participation in the study was voluntary and the tourists were assured that the collected data would remain confidential. Data collection lasted an entire month. Out of the 400 distributed questionnaires, 380 were returned and used for data analysis.

\subsection{Data Analysis and Results}

To analyze the gleaned data, descriptive statistics (e.g., gender, age, academic degree, etc.) were initially produced, followed by running inferential statistics. The study utilized partial least squares (PLS) with Smart PLS 3.0 to validate the measurement model and test the hypotheses. PLS has some advantages in comparison with the covariance-based approach (LISREL), e.g., high capability in predicting the model [72,73], development of new models, capability to assess both reflective and formative measurement models, insensitivity to normality of distribution and sample size, and capability to test complicated models [25]. Composite reliability (CR) and Cronbach's alpha were used to gauge internal consistency, with the results yielding acceptable indices for all the variables. Furthermore, average variance extracted (AVE) was employed to assess validity in the model variables. The results indicated internal validity of the measurement model.

\subsection{Findings}

Out of the 400 distributed questionnaires, 380 were completed and returned. As shown in Table 2, about $46.8 \%$ of the respondents were female, while $53.0 \%$ were male. With respect to academic qualifications, $17 \%$ of the participants had an associate diploma, $53 \%$ held a bachelor's degree, and 35\% possessed a graduate degree.

The results indicated that $27 \%$ of the participants used STTs before starting the trip. Furthermore, $73.15 \%$ reported using such technologies while planning for the trip, and $97.36 \%$ exploited these technologies during travel. About $21.8 \%$ of the respondents were Generation Y, followed by Generation X (39.5\%), Generation Z (11.6\%) and Baby Boomers (27.1\%). 
Table 2. Demographic Profile of the research population.

\begin{tabular}{|c|c|c|c|c|c|}
\hline Characteristics & & Frequency $\%$ & Characteristics & & Frequency $\%$ \\
\hline \multirow{4}{*}{ Gender } & \multirow[b]{2}{*}{ Female } & \multirow[b]{2}{*}{$187(46.8)$} & \multirow{5}{*}{ Education } & Less than high school & $25(6.6)$ \\
\hline & & & & $\begin{array}{l}\text { High school degree } \\
\text { or equivalent }\end{array}$ & $55(14)$ \\
\hline & \multirow{2}{*}{ Male } & \multirow{2}{*}{$202(53.2)$} & & Bachelor degree & $200(53)$ \\
\hline & & & & Associate degree & $65(17)$ \\
\hline \multirow{5}{*}{ Age } & \multirow{2}{*}{$1963-80$} & \multirow{2}{*}{$150(39.5)$} & & Graduate degree & $35(9.2)$ \\
\hline & & & \multirow{4}{*}{$\begin{array}{l}\text { Smart devices } \\
\text { used at the } \\
\text { destination }\end{array}$} & Smartphone & $361(95)$ \\
\hline & $1981-2000$ & $83(21.8)$ & & Smart watches & $10(2.63)$ \\
\hline & \multirow{2}{*}{ From 2001 until now. } & \multirow{2}{*}{$147(38.7)$} & & Tablet & $15(3.95)$ \\
\hline & & & & other & $25(6.51)$ \\
\hline \multirow{3}{*}{$\begin{array}{l}\text { Stage of trip } \\
\text { using STTs }\end{array}$} & Before a trip & $101(27)$ & \multirow{3}{*}{ Purpose } & For business & $110(28.9)$ \\
\hline & While planning & $278(73.15)$ & & For pleasure & $200(52.6)$ \\
\hline & While traveling & $370(97.36)$ & & $\begin{array}{l}\text { For both business and } \\
\text { pleasure Other }\end{array}$ & $70(18.4)$ \\
\hline
\end{tabular}

\subsection{Measuring the Research Model Reliability}

In order to examine reliability of the measurement model, several items including factor loadings, Cronbach's alpha, and composite reliability were estimated (Table 3). Factor loadings were obtained through calculating the correlation among different items measuring a construct. The cut-off point for factor loading was 0.4 [73]. According to the results, all factor loadings were greater than the cut-off score, demonstrating the suitability of the developed model. Cronbach's alpha is a classic yardstick for gauging internal consistency. Values greater than 0.70 illustrate acceptable reliability [74]. Since the Cronbach's alphas for the study variables were larger than 0.70 , all the variables have acceptable reliability. The composite reliability was proposed by Wortes, Lin, and Jorskog (1974). A variable with a composite reliability index above 0.4 is reliable. All the variables have appropriate internal consistency for the measurement model. Divergent discriminant validity is another index used to measure the fitness of measurement models in the PLS. Fornell and Larcker [73] introduced average variance extracted (AVE) to measure convergent validity. They estimated the critical value to be about 0.5 . The findings of this research showed that convergent validity was supported by AVE values exceeding 0.5 . The measurement items were loaded more highly on their own latent construct than on other constructs. The square root of AVE of each construct was larger than the correlation coefficients involving the construct, thus confirming discriminant validity [72].

Table 3. Results of the measurement model.

\begin{tabular}{cc}
\hline Measure & Factor Loading \\
\hline Tourist attitude (composite reliability = 0.939; Cronbach $\boldsymbol{\alpha}=\mathbf{0 . 9 0 4}$; AVE = 0.608) & 0.709 \\
\hline I expect that tourist destinations use STTs. & 0.809 \\
\hline STTs help me deviate from routine activities in my travel. & 0.821 \\
\hline The presence of STTs infrastructure affects my attitude toward visiting the destination. & 0.786 \\
\hline STT helps me gain unique experiences. & 0.907 \\
\hline Tourist perceived behavior control(composite reliability = 0.929; Cronbach $\boldsymbol{\alpha}=\mathbf{0 . 8 8 5}$; AVE $\mathbf{0 . 8 1 3 )}$ & 0.919 \\
\hline I utilize STTs in my travels to gain new experiences and recommend it to others. & 0.879 \\
\hline I am sure I can use STTs during my travel if I want to. & \\
\hline I have enough resources, time, and opportunity to use STTs during my travel. & \\
\hline
\end{tabular}


Table 3. Cont.

\begin{tabular}{|c|c|}
\hline Measure & Factor Loading \\
\hline \multicolumn{2}{|l|}{ Tourist subjective norms (composite reliability $=0.896$; Cronbach $\alpha=0.825 ; \mathrm{AVE}=0.742$ ) } \\
\hline People who I trust expect me to use STTs during my travel to gain unique experiences. & 0.912 \\
\hline My family / friends believe that I should use STTs during my travel to gain unique experiences. & 0.851 \\
\hline Some people argue that I should use STTs during my travel to gain unique experiences. & 0.818 \\
\hline \multicolumn{2}{|l|}{ Exploitative use of STTs (composite reliability $=0.863$; Cronbach $\alpha=0.774 ; \mathrm{AVE}=0.677$ ) } \\
\hline $\begin{array}{l}\text { I intend to use my smart phone applications in my future travel to compare and select smart facilities and infrastructure (e.g., } \\
\text { ticket sellers, lodges, and dining). }\end{array}$ & 0.732 \\
\hline $\begin{array}{l}\text { I intend to use web-based technologies (e.g., personal weblogs, websites specialized in tourism, etc.) in my future travel to } \\
\text { compare and select smart facilities and infrastructure. }\end{array}$ & 0.876 \\
\hline I intend to use social networks in my future travel to compare and select smart facilities and infrastructure. & 0.844 \\
\hline \multicolumn{2}{|l|}{ Explorative use of STTs (composite reliability = 0.859; Cronbach $\alpha=0.774 ; \mathrm{AVE}=0.672$ ) } \\
\hline $\begin{array}{l}\text { I intend to use smart phone applications (e.g., location-based apps as well as apps used for booking tickets and hotels, } \\
\text { checking traffic status/pollution, etc.) to explore smart attractions and activities in the destination. }\end{array}$ & 0.802 \\
\hline I intend to use social networks to explore smart attractions and activities in the destination. & 0.836 \\
\hline I intend to use web-based technologies to explore smart attractions and activities in the destination. & 0.830 \\
\hline \multicolumn{2}{|l|}{ Memorable experiences $($ composite reliability $=0.916$; Cronbach $\alpha=0.903 ; \mathrm{AVE}=0.785$ ) } \\
\hline Smart technology applications create exciting memories (memorable experiences) for me. & 0.881 \\
\hline Smart technology applications make my travel pleasant through creating unique experiences. & 0811 \\
\hline Smart technology applications create more memorable experiences during my travel. & 0919 \\
\hline \multicolumn{2}{|l|}{ Satisfaction (composite reliability $=0.826 ;$ Cronbach $\alpha=0.701 ;$ AVE $=0.615$ ) } \\
\hline The quality of STTs can enhance my satisfaction with the destination. & 0.700 \\
\hline Destinations that STTs offer beyond my expectations make my travel more pleasant. & 0.842 \\
\hline Gaining unique experiences via STTs is one of my ideals and makes me happy. & 0.817 \\
\hline \multicolumn{2}{|l|}{ Revisit intention (composite reliability $=0.840 ;$ Cronbach $\alpha=0.904 ; \mathrm{AVE}=0.637$ ) } \\
\hline In future, I will travel to destinations that offer unique experiences via STTs. & 0.799 \\
\hline I recommend destinations that use unique STTs to my family and friends. & 0.833 \\
\hline I share my memorable experiences gained via STTs with others. & 0.762 \\
\hline
\end{tabular}

Note: AVE = average variance extracted.

Comparing the average root of the AVE variables with the latent variables (LV) correlations and the square root of each should be greater than its highest correlation with

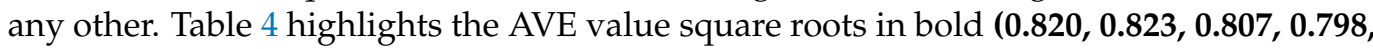
$0.886,0.748,0.902,0.780$, and 0.861$)$ and establishes discriminant validity as they all meet the requirement [11].

\subsection{Hypothesis Testing}

Table 5 demonstrates the results of the study. Accordingly, tourists' attitudes have a significant positive effect on intention toward the exploitative use of technology ( $\mathrm{T}=4.05$, $\beta=0.163, p<0.000)$ and intention toward explorative use $(\mathrm{T}=27.25, \beta=0.724, p<0.000)$. Moreover, tourists' subjective norms have a significant positive impact on their intention toward exploitative $(\mathrm{T}=13.81, \beta=0.542, p<0.003)$ and explorative use of technology $(\mathrm{T}=3.03, \beta=0.110, p<0.000)$. Tourists' perceived behavioral control also has a positive influence on their intention toward exploitative use $(T=6.01, \beta=0.284, p<0.002)$. Similar relations are also observed regarding tourist's intention toward explorative use $(\mathrm{T}=3.15$, $\beta=0.117, p<0.000)$, and memorable experiences $(\mathrm{T}=13.30, \beta=0.315, p<0.000)$. According to the results, attitudes, subjective norms, and perceived behavioral controls accounted for $67 \%$ and $64 \%$ of the variance in intention toward explorative and exploitative uses, respectively. We further found that tourists' intentions toward explorative use has a significant positive impact on memorable experiences $(T=13.77, \beta=0.528, p<0.000)$. 
Moreover, tourists' intentions toward exploitative use has a significant positive effect on their memorable experiences $(T=6.77, \beta=0.249, p<0.000)$.

Table 4. Discriminant validity.

\begin{tabular}{|c|c|c|c|c|c|c|c|c|}
\hline & $\begin{array}{l}\text { Exploitative } \\
\text { Use of } \\
\text { STTs }\end{array}$ & $\begin{array}{l}\text { Explorative } \\
\text { Use of } \\
\text { STTs }\end{array}$ & $\begin{array}{l}\text { Revisit } \\
\text { Intention }\end{array}$ & $\begin{array}{l}\text { Memorable } \\
\text { Experience }\end{array}$ & Satisfaction & $\begin{array}{c}\text { Tourist } \\
\text { Perceived } \\
\text { Behavior } \\
\text { Control }\end{array}$ & $\begin{array}{l}\text { Tourist's } \\
\text { Attitude }\end{array}$ & $\begin{array}{c}\text { Tourist } \\
\text { Subjective } \\
\text { Norms }\end{array}$ \\
\hline Exploitative use of STTs & 0.820 & & & & & & & \\
\hline Explorative use of STTs & 0.546 & 0.823 & & & & & & \\
\hline Revisit intention & 0.473 & 0.338 & 0.798 & & & & & \\
\hline Memorable Experience & 0.883 & 0.726 & 0.583 & 0.886 & & & & \\
\hline Satisfaction & 0.719 & 0.372 & 0.524 & 0.668 & 0.784 & & & \\
\hline $\begin{array}{l}\text { Tourist perceived } \\
\text { behavior control }\end{array}$ & 0.616 & 0.454 & 0.265 & 0.774 & 0.450 & 0.902 & & \\
\hline Tourist's attitude & 0.437 & 0.803 & 0.277 & 0.590 & 0.279 & 0.390 & 0.780 & \\
\hline $\begin{array}{l}\text { Tourist's beliefs and } \\
\text { subjective norms }\end{array}$ & 0.732 & 0.387 & 0.413 & 0.638 & 0.860 & 0.495 & 0.303 & 0.861 \\
\hline
\end{tabular}

Table 5. Path coefficient and hypothesis testing.

\begin{tabular}{ccccc}
\hline Hypothesis & Direct Influence $(\boldsymbol{\beta})$ & T-Value & $p$-Value & Results \\
\hline H1: Tourist attitude $\rightarrow(+)$ Exploitative use of STTs & 0.163 & 13.816 & 0 & Supported \\
\hline H2: Tourist attitude $\rightarrow(+)$ Explorative use of STT & 0.724 & 3.032 & 0 & Supported \\
\hline H3: Subjective norms $\rightarrow(+)$ Exploitative use of STTs & 0.542 & 4.055 & 0 & Supported \\
\hline H4: Subjective norms $\rightarrow(+)$ Explorative use of STT & 0.11 & 27.253 & 0.003 & Supported \\
\hline H5: Perceived behavioral control $\rightarrow(+)$ Exploitative use of STTs & 0.284 & 6.017 & 0 & Supported \\
\hline H6: Perceived behavioral control $\rightarrow(+)$ Explorative use of STT & 0.117 & 3.152 & 0.002 & Supported \\
\hline H7: Perceived behavioral control $\rightarrow(+)$ Memorable Experience & 0.315 & 13.306 & 0 & Supported \\
\hline H8: Exploitative use of STTs $\rightarrow(+)$ Memorable Experience & 0.528 & 21.102 & 0 & Supported \\
\hline H9: Explorative use of STTs $\rightarrow(+)$ Memorable Experience & 0.294 & 13.775 & 0 & Supported \\
\hline H10: Memorable Experience $\rightarrow(+)$ Satisfaction & 0.668 & 23.031 & 0 & Supported \\
\hline H11: Memorable Experience $\rightarrow(+)$ Revisit intention & 0.421 & 6.231 & 0 & Supported \\
\hline H12: Satisfaction $\rightarrow(+)$ Revisit intention & 0.243 & 3.389 & 0.001 & Supported \\
\hline
\end{tabular}

According to Figure 2, intention toward explorative use, intention toward exploitative use, and perceived behavioral control can explain $92 \%$ of the variance of memorable experiences. Overall, the results imply that tourists' memorable experiences have a significant positive impact on their satisfaction $(\mathrm{T}=23.03, \beta=0.668, p<0.000)$ and intention to revisit $(\mathrm{T}=6.23, \beta=0.421, p<0.000)$. There is also a significant positive relationship between tourists' satisfaction and their revisit intention $(T=3.38, \beta=0.243, p<0.001)$. Figure 2 also shows that tourists' memorable experiences account for $44 \%$ of the variance in their satisfaction. Finally, tourists' memorable experience, coupled with their satisfaction, can explain $37 \%$ of the variance in intention to revisit. 


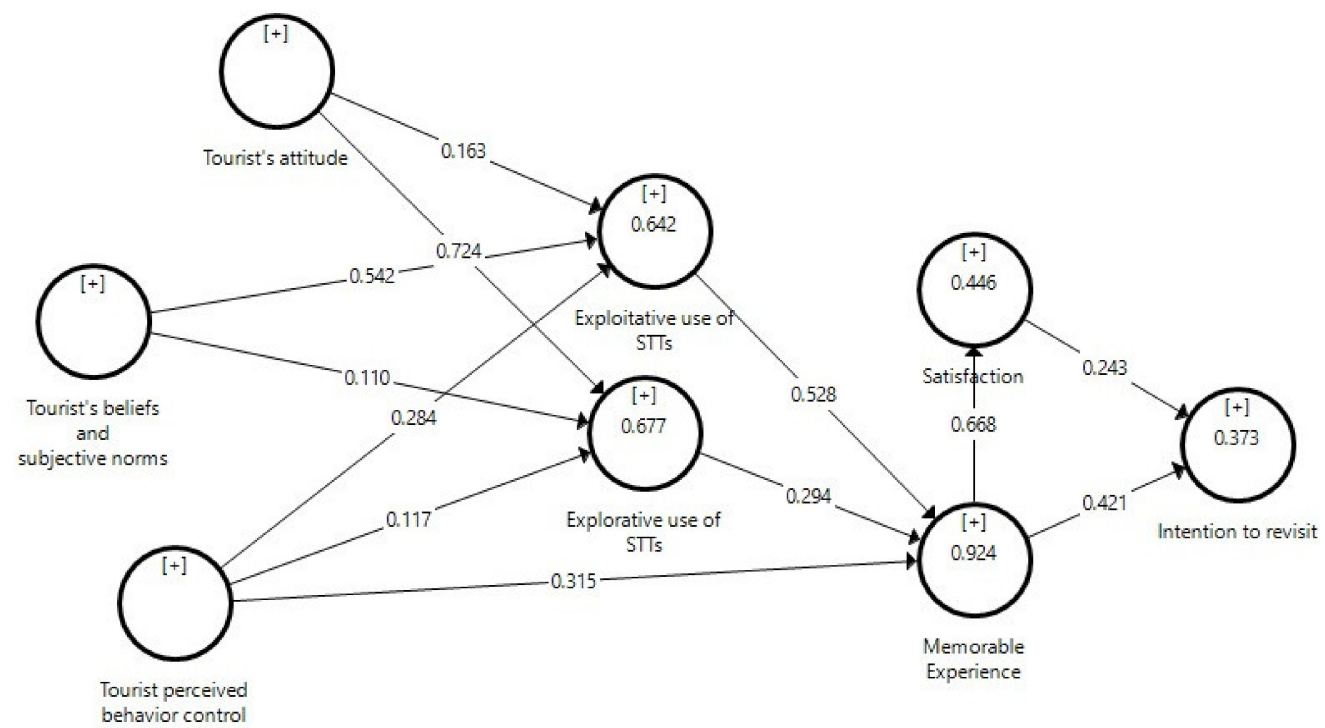

Figure 2. Research model result. The positive sign demonstrates a positive association. $\mathrm{T}$ and the number between lines indicates the extent of the relationship.

\section{Discussion}

From the literature, it was established that one key and critical aspect in tourism is ensuring that visitors experience unmetered satisfaction. As this would influence their decision and intention to revisit but would also have a positive impact through positive reviews by tourist users. This argument was also affirmed in this study where it was established that tourists' memorable activities have a significant, positive effect on their satisfaction and revisit intention in destinations.

Therefore, bilateral value will be created if smart destinations meet tourists' needs and offer services in a way to promote memorable experiences. In such a situation, the ultimate goal, which is tourists' satisfaction and revisit intention, will be achieved.

With the reality of COVID-19 and the disruption that it prompted in different sectors especially in the tourism sector, it is expected that explorative and exploitative use of STTs will increase, especially in view of emerging advanced technologies. On this, Petrovic et al. [75] noted that technologies such as Augmented Reality (AR) and Gamified Sightseeing, leveraging on increasing data and data computation technologies are expected to become part of STTs. This will not only have positive impacts on different cities like Tehran that are trying to recover from the devastating impacts of the pandemic but are expected to give visitors even more options in the pursuit of satisfaction and memorable experiences. However, for cities to have capacities to leverage on these emerging technologies, it will require them to increase their investment in technology infrastructures that would allow seamless and unmetered experience by the tourists (both locals and visiting ones) [3,76,77]. However, as noted in the literature review, changes in behavior are influenced by a number of factors. In this case, for cities to manage to attract and influence behavioral change amongst their tourism target groups, they will need to understand the different demographic characteristics of the visitors and hence, customize the STTs accordingly. In this study, the highest percentage of those interviewed were those born between 1980 until now, and this, represents a technological savvy group. Therefore, it is highly likely that a majority of these will be interested in STTs, not only while travelling, which was reported to be the most prominent time that people use STTs, but even before planning for the trips. This information is important for city managers as they can ensure they incorporate STTs in their economic recovery programs $[78,79]$. The use of smart devices, especially smart phones has been identified in this report and others as the most prominent and widely used by visitors in their search for memorable experiences. This means that infrastructures that support fast connectivity such as $4 \mathrm{G}$ and $5 \mathrm{G}$ technologies could be given priorities to ensure that 
trends such as sharing of information from different destination is enhanced [80]. They are expected to have even more influence on enhancing the adoption of emerging technologies such as AR and Gamified Sightseeing that are expected to gain more popularity following the health protocols that are still in force in some touristic destinations. However, for cities, in-person visits would be more profitable as it has been argued to have multiplier effects on other sectors. As such, pursuing increased vaccinations against COVID-19 need to be enhanced to ensure tourism destinations are gradually reopened and diverse tourism activities resumes.

\section{Theoretical and Practical Implications}

The findings offer promising theoretical issues and enrich the literature on smart tourism from different perspectives. First, the study focused on domestic tourists, who have received scant attention in the smart tourism literature. Second, it concentrated on Tehran, the capital of Iran, which has not been thoroughly investigated in the smart tourism literature. Third, this study is one of the first attempts trying to establish an association between the process of shaping behavioral decisions and satisfaction with and revisit intention smart destinations using STTs. Fourth, this study showed that tourists' intentions toward explorative and exploitative use of STTs positively affected their memorable experiences, an issue that had not been previously explored. Fifth, the results demonstrated that tourists' attitudes, subjective norms, and perceived behavioral control were relatively strong predictors of their intention toward explorative and exploitative use of STTs.

This study examines the application of SST in destination and marketer management to encourage positive customer loyalty, memorable experience, and customer revisits intention. Therefore, it has tried to answer two key questions: How do norms, perceived behavioral control, and attitudes towards STTs influence their utility? How does the use of STTs affect memorable experiences, satisfaction, and revisit intention? The findings indicate that STTs are a significant obstacle for marketers and managers because they need to use creative and inventive marketing tactics to keep up with competitors. When smart destination marketers focus on people's subjective norms, perceived behavioral control, and attitude towards tourism technologies, they can enhance a memorable experience, satisfaction, and revisit intention. According to the factors that influence tourists' behavior, tourism organization officials should provide STTs appropriate for tourists. If the tendency is to exploit smart technologies, simple technologies should be considered to compare and select smart facilities and infrastructure. However, if tourists use smart technologies to discover new tourism attractions and activities, they need to provide more sophisticated technology at different stages of the journey.

This study attempts to identify the role that the exploitative and explorative use of STTs play in tourists' revisit intention in Tehran. In line with Koo, Chung, and Kim [25], this study indicated that tourists' attitudes, subjective norms, and perceived behavioral control are predictors of exploitative and explorative uses of STTs. The study findings are also consistent with previous studies $[10,15,54-56]$, which pointed out that tourists' attitudes are a significant predictor of their behavioral intention. Besides, in line with Huang et al. [1], this study found that tourists' intention toward explorative and exploitative uses of STTs has a significant positive impact on memorable experiences. It also indicated that the latter variable positively impacts satisfaction and revisit intention. Therefore, intention toward explorative and exploitative uses of STTs, and perceived behavioral control can indirectly affect tourists' revisit intention through effecting memorable experiences. These findings are in line with Chen and Rahman [66] in Taiwan, Wong et al. [81] in China, and Jeong and Shin [22] in the US, who believe that STTs can provide the opportunity for tourists to have a memorable experience.

The current study offers valuable insights about how using STTs can promote memorable experiences and influence tourists' satisfaction with and intention to revisit the destination. Nonetheless, its limitations should be admitted. First, this study solely focused on domestic tourists travelling to Tehran. Thus, caution must be exercised in generalizing 
the findings to other cultural groups with various levels of technology use, especially international. Furthermore, a convenience sampling method was used to collect the data. Since a convenience sample does not represent the entire population, a correct sampling method should be used in future research.

A limited number of studies have examined the effect of explorative/exploitative use of STTs in tourism, in general, and smart tourism, in particular. Interesting findings may be revealed by carrying out further research in this area. Furthermore, Iran has faced several challenges such as developing smart infra-structure due to the recent sanctions, filtering some information-produced platforms such as Facebook, Twitter, Telegram, etc., which could have affected the STTs' user experience in this research.

\section{Conclusions}

The results of the study indicate that tourists' attitudes, subjective norms, and perceived behavioral control had a significant, positive effect on their intention toward explorative and exploitative use of STTs. Jeong and Shin [22] believe that it is impossible nowadays for many tourists not to use STTs as they have invaluable benefits. Tourists' positive attitude, subjective norms, and perceived behavioral control toward STTs have promoted the role of smart technology in tourists' search, exploration, innovation, comparison, and selection of activities and attractions during the travel plan. It has also had a positive influence on the tourists as they attempt to share events, find routes, book accommodation and tickets for different destinations and activities [82-84], and establish better relationships with local communities during their travel. With regard to subjective norms, the findings of this study fit with the ideas proposed by Ghaderi et al. (2019) who argued that tourists make attempts to adapt their behaviors in light of their surrounding condition and people. The results of this study also showed that people with stronger motivation and less barriers who use STTs had higher intention toward explorative and exploitative use. Moreover, stronger motivation and less barriers to use STTs facilitate tourists' use of STTs, hence more memorable experiences for them.

The results of this study also indicated that intention toward explorative and exploitative use of STTs positively influence tourists' memorable experiences. Thus, tourists' intention to search, explore, compare, and select smart attractions and activities can enhance their memorable experiences. However, they have been found to be influenced by availability of supporting infrastructure. On this, smart technologies make it feasible for tourists to discover notable attractions and activities in the chosen destination, hence gaining an experience that other tourists, who are not within smart city enabled environments, are deprived of [28]. In their study Ghaderi et al. [11] found that smart destinations can create opportunities for gaining memorable experiences for tourists by allowing for trends such as booking accommodations and tickets, searching and virtually exploring diverse routes for a specific destination, recording of events, and sharing them. Smart destinations further allow tourists to establish better relationships with local communities and find unique areas matching their specific interests.

Author Contributions: Conceptualization and formal analysis: Z.-A.T.; writing-original draft preparation, review and editing: Z.-A.T., Z.A., A.A.S.; Z.G., B.M. \& A.R.K.-G. All authors have read and agreed to the published version of the manuscript.

Funding: This research received no external funding.

Institutional Review Board Statement: Not applicable.

Informed Consent Statement: Not applicable.

Data Availability Statement: Not applicable.

Conflicts of Interest: The authors declare no conflict of interest. 


\section{References}

1. Huang, C.D.; Goo, J.; Nam, K.; Yoo, C.W. Smart tourism technologies in travel planning: The role of exploration and exploitation. Inf. Manag. 2017, 54, 757-770. [CrossRef]

2. Han, H.; Hsu, L.T.; Sheu, C. Application of the Theory of Planned Behavior to green hotel choice: Testing the effect of environmental friendly activities. Tour. Manag. 2010, 31, 325-334. [CrossRef]

3. Allam, Z. On Culture, Technology and Global Cities. In Cities and the Digital Revolution; Springer: Berlin/Heidelberg, Germany, 2020; pp. 107-124.

4. Han, D.-I.; Jung, T.; Gibson, A. Dublin AR: Implementing Augmented Reality in Tourism. In Information and Communication Technologies in Tourism 2014; Springer: Berlin/Heidelberg, Germany, 2013; pp. 511-523.

5. Femenia-Serra, F.; Ivars-Baidal, J.A. Do smart tourism destinations really work? The case of Benidorm. Asia Pacific J. Tour. Res. 2021, 26, 365-384. [CrossRef]

6. Lee, H.; Lee, J.; Chung, N.; Koo, C. Tourists' happiness: Are there smart tourism technology effects? Asia Pacific J. Tour. Res. 2018, 23, 486-501. [CrossRef]

7. Jovicic, D.Z. From the traditional understanding of tourism destination to the smart tourism destination. Curr. Issues Tour. 2019, 22, 276-282. [CrossRef]

8. Cornelisse, M. Understanding memorable tourism experiences: A case study. Res. Hosp. Manag. 2018, 8, 93-99. [CrossRef]

9. Ajzen, I. The theory of planned behavior. Organ. Behav. Hum. Decis. Process. 2012, 50, 179-211. [CrossRef]

10. Lam, T.; Hsu, C.H.C. Predicting behavioral intention of choosing a travel destination. Tour. Manag. 2006, 27, 589-599. [CrossRef]

11. Ghaderi, Z.; Hatamifar, P.; Ghahramani, L. How smartphones enhance local tourism experiences? Asia Pacific J. Tour. Res. 2019, 24 778-788. [CrossRef]

12. Torabi, Z.A.; Rezvani, M.R.; Palouj, M. Comparing the Effect of Lecture and Jigsaw Teaching Strategies on Attitude and Environmentally Responsible Behavior: A Mixed-methods Approach. J. Qual. Assur. Hosp. Tour. 2021, 1-24. [CrossRef]

13. Park, S.H.; Hsieh, C.M.; Lee, C.K. Examining Chinese College Students' Intention to Travel to Japan Using the Extended Theory of Planned Behavior: Testing Destination Image and the Mediating Role of Travel Constraints. J. Travel Tour. Mark. 2017, 34, 113-131. [CrossRef]

14. Guan, M.; Coles, V.B.; Samp, J.A.; Sales, J.M.D.; DiClemente, R.J.; Monahan, J.L. Incorporating Communication into the Theory of Planned Behavior to Predict Condom Use among African American Women. J. Health Commun. 2016, 21, 1046-1054. [CrossRef]

15. Lam, T.; Hsu, C.H.C. Theory of Planned Behavior: Potential Travelers from China. J. Hosp. Tour. Res. 2004, 28, 463-482. [CrossRef]

16. Ajzen, I. From Intentions to Actions: A Theory of Planned Behavior. In Action Control; Springer: Berlin/Heidelberg, Germany, 1985; pp. 11-39.

17. Hsu, C.H.C.; Huang, S. An Extension of the Theory of Planned Behavior Model for Tourists. J. Hosp. Tour. Res. 2012, 36, 390-417. [CrossRef]

18. Wong, J.W.C.; Lai, I.K.W.; Tao, Z. Sharing memorable tourism experiences on mobile social media and how it influences further travel decisions. Curr. Issues Tour. 2020, 23, 1773-1787. [CrossRef]

19. Tan, W.K. The relationship between smartphone usage, tourist experience and trip satisfaction in the context of a nature-based destination. Telemat. Inform. 2017, 34, 614-627. [CrossRef]

20. Wang, D.; Park, S.; Fesenmaier, D.R. The Role of Smartphones in Mediating the Touristic Experience. J. Travel Res. 2012, 51, 371-387. [CrossRef]

21. Buhalis, D.; Amaranggana, A. Smart Tourism Destinations Enhancing Tourism Experience Through Personalisation of Services. In Information and Communication Technologies in Tourism 2015; Springer: Berlin/Heidelberg, Germany, 2015; pp. 377-389.

22. Jeong, M.; Shin, H.H. Tourists' Experiences with Smart Tourism Technology at Smart Destinations and Their Behavior Intentions. J. Travel Res. 2020, 59, 1464-1477. [CrossRef]

23. Auh, S.; Menguc, B. Balancing exploration and exploitation: The moderating role of competitive intensity. J. Bus. Res. 2005, 58, 1652-1661. [CrossRef]

24. Durcikova, A.; Fadel, K.J.; Butler, B.S.; Galletta, D.F. Knowledge exploration and exploitation: The impacts of psychological climate and knowledge management system access. Inf. Syst. Res. 2011, 22, 855-866. [CrossRef]

25. Koo, C.; Chung, N.; Kim, H.W. Examining explorative and exploitative uses of smartphones: A user competence perspective. Inf. Technol. People 2015, 28, 133-162. [CrossRef]

26. Girish, V.G.; Chen, C.F. Authenticity, experience, and loyalty in the festival context: Evidence from the San Fermin festival, Spain Curr. Issues Tour. 2017, 20, 1551-1556. [CrossRef]

27. Chen, C.F.; Chen, F.S. Experience quality, perceived value, satisfaction and behavioral intentions for heritage tourists. Tour. Manag. 2010, 31, 29-35. [CrossRef]

28. Wang, D.; Xiang, Z.; Fesenmaier, D.R. Smartphone Use in Everyday Life and Travel. J. Travel Res. 2016, 55, 52-63. [CrossRef]

29. Kim, J.H. The Impact of Memorable Tourism Experiences on Loyalty Behaviors: The Mediating Effects of Destination Image and Satisfaction. J. Travel Res. 2018, 57, 856-870. [CrossRef]

30. Nguyen, T.; Lee, K.; Chung, N.; Koo, C. The way of generation Y enjoying Jazz festival: A case of the Korea (Jarasum) music festival. Asia Pacific J. Tour. Res. 2020, 25, 52-63. [CrossRef]

31. Chinomona, R.; Sandada, M. Predictors Of Customer Loyalty To Mobile Service Provider In South Africa. Int. Bus. Econ. Res. J. 2013, 12, 1631. [CrossRef] 
32. Akhoondnejad, A. Tourist loyalty to a local cultural event: The case of Turkmen handicrafts festival. Tour. Manag. 2016, 52, 468-477. [CrossRef]

33. Meng, B.; Han, H. Working-holiday tourism attributes and satisfaction in forming word-of-mouth and revisit intentions: Impact of quantity and quality of intergroup contact. J. Destin. Mark. Manag. 2018, 9, 347-357. [CrossRef]

34. Zhang, H.; Wu, Y.; Buhalis, D. A model of perceived image, memorable tourism experiences and revisit intention. J. Destin. Mark. Manag. 2018, 8, 326-336. [CrossRef]

35. Li, F.; Wen, J.; Ying, T. The influence of crisis on tourists' perceived destination image and revisit intention: An exploratory study of Chinese tourists to North Korea. J. Destin. Mark. Manag. 2018, 9, 104-111. [CrossRef]

36. Nouri, Z.; Rafieian, M.; Ghasemi, K. Using information and communication technologies to create learning urban public space (Case study: Central part of Tehran, Iran). Habitat Int. 2019, 87, 91-98. [CrossRef]

37. Jelokhani-Niaraki, M.; Hajiloo, F.; Samany, N.N. A Web-based Public Participation GIS for assessing the age-friendliness of cities: A case study in Tehran, Iran. Cities 2019, 95, 102471. [CrossRef]

38. Hollands, R.G. Will the real smart city please stand up? Intelligent, progressive or entrepreneurial? City 2008, 12, 303-320 [CrossRef]

39. Hollands, R.G. Critical interventions into the corporate smart city. Cambridge J. Reg. Econ. Soc. 2015, 8, 61-77. [CrossRef]

40. Wang, X.; Li, X.R.; Zhen, F.; Zhang, J.H. How smart is your tourist attraction?: Measuring tourist preferences of smart tourism attractions via a FCEM-AHP and IPA approach. Tour. Manag. 2016, 54, 309-320. [CrossRef]

41. Weaver, D.B.; Moyle, B.D. 'Tourist stupidity' as a basic characteristic of 'smart tourism': Challenges for destination planning and management. Tour. Recreat. Res. 2019, 44, 387-391. [CrossRef]

42. Adeola, O.; Evans, O. Digital tourism: Mobile phones, internet and tourism in Africa. Tour. Recreat. Res. 2019, 44, 190-202. [CrossRef]

43. Kim, D.; Kim, S. The role of mobile technology in tourism: Patents, articles, news, and mobile tour app reviews. Sustainability 2017, 9, 2082. [CrossRef]

44. Li, Y.; Hu, C.; Huang, C.; Duan, L. The concept of smart tourism in the context of tourism information services. Tour. Manag. 2017, 58, 293-300. [CrossRef]

45. Hrubes, D.; Ajzen, I.; Daigle, J. Predicting hunting intentions and behavior: An application of the theory of planned behavior. Leis. Sci. 2001, 23, 165-178. [CrossRef]

46. Chen, M.F.; Tung, P.J. Developing an extended Theory of Planned Behavior model to predict consumers' intention to visit green hotels. Int. J. Hosp. Manag. 2014, 36, 221-230. [CrossRef]

47. Wang, C.; Zhang, J.; Yu, P.; Hu, H. The theory of planned behavior as a model for understanding tourists' responsible environmental behaviors: The moderating role of environmental interpretations. J. Clean. Prod. 2018, 194, 425-434. [CrossRef]

48. Conner, M.; Armitage, C.J. Extending the theory of planned behavior: A review and avenues for further research. J. Appl. Soc. Psychol. 1998, 28, 1429-1464. [CrossRef]

49. Chung, N.; Lee, H.; Kim, J.Y.; Koo, C. The Role of Augmented Reality for Experience-Influenced Environments: The Case of Cultural Heritage Tourism in Korea. J. Travel Res. 2018, 57, 627-643. [CrossRef]

50. Xiang, Z.; Wang, D.; O'Leary, J.T.; Fesenmaier, D.R. Adapting to the Internet: Trends in Travelers' Use of the Web for Trip Planning. J. Travel Res. 2015, 54, 511-527. [CrossRef]

51. Minghetti, V.; Buhalis, D. Digital divide in tourism. J. Travel Res. 2010, 49, 267-281. [CrossRef]

52. Levinthal, D.A.; March, J.G. The myopia of learning. Strateg. Manag. J. 1993, 14, 95-112. [CrossRef]

53. Quintal, V.A.; Thomas, B.; Phau, I. Incorporating the winescape into the theory of planned behaviour: Examining "new world" wineries. Tour. Manag. 2015, 46, 596-609. [CrossRef]

54. Casaló, L.V.; Flavián, C.; Guinalíu, M. Determinants of the intention to participate in firm-hosted online travel communities and effects on consumer behavioral intentions. Tour. Manag. 2010, 31, 898-911. [CrossRef]

55. Han, H. Travelers' pro-environmental behavior in a green lodging context: Converging value-belief-norm theory and the theory of planned behavior. Tour. Manag. 2015, 47, 164-177. [CrossRef]

56. Ayeh, J.K.; Au, N.; Law, R. Predicting the intention to use consumer-generated media for travel planning. Tour. Manag. 2013, 35, 132-143. [CrossRef]

57. Wang, J.; Ritchie, B.W. Understanding accommodation managers' crisis planning intention: An application of the theory of planned behaviour. Tour. Manag. 2012, 33, 1057-1067. [CrossRef]

58. He, Z.L.; Wong, P.K. Exploration vs. exploitation: An empirical test of the ambidexterity hypothesis. Organ. Sci. 2004, 15, 481-495. [CrossRef]

59. Burton-Jones, A.; Straub, D.W. Reconceptualizing system usage: An approach and empirical test. Inf. Syst. Res. 2006, 17, 228-246. [CrossRef]

60. March, J.G. Exploration and Exploitation in Organizational Learning. Organ. Sci. 1991, 2, 71-87. [CrossRef]

61. Subramani, M. How do suppliers benefit from information technology use in supply chain relationships? MIS Q. Manag. Inf. Syst. 2004, 28, 45-73. [CrossRef]

62. Lee, Y.J. Creating memorable experiences in a reuse heritage site. Ann. Tour. Res. 2015, 55, 155-170. [CrossRef]

63. Chandralal, L.; Rindfleish, J.; Valenzuela, F. An Application of Travel Blog Narratives to Explore Memorable Tourism Experiences. Asia Pacific J. Tour. Res. 2015, 20, 680-693. [CrossRef] 
64. Campos, A.C.; Mendes, J.; do Valle, P.O.; Scott, N. Co-creation of tourist experiences: A literature review. Curr. Issues Tour. 2018, 21, 369-400. [CrossRef]

65. Kim, H.H.; Law, R. Smartphones in Tourism and Hospitality Marketing: A Literature Review. J. Travel Tour. Mark. 2015, 32, 692-711. [CrossRef]

66. Chen, H.; Rahman, I. Cultural tourism: An analysis of engagement, cultural contact, memorable tourism experience and destination loyalty. Tour. Manag. Perspect. 2018, 26, 153-163. [CrossRef]

67. Yoo, C.W.; Goo, J.; Huang, C.D.; Nam, K.; Woo, M. Improving travel decision support satisfaction with smart tourism technologies: A framework of tourist elaboration likelihood and self-efficacy. Technol. Forecast. Soc. Change 2017, 123, 330-341. [CrossRef]

68. Sthapit, E.; Del Chiappa, G.; Coudounaris, D.N.; Björk, P. Tourism experiences, memorability and behavioural intentions: A study of tourists in Sardinia, Italy. Tour. Rev. 2020, 75, 533-558. [CrossRef]

69. Tassawa, C.; Banjongprasert, J. An investigation of international tourists on tourists satisfation, tourist experience and destination loyalty. Humanit. Arts Soc. Sci. Stud. 2019, 19, 649-674.

70. Amirahmadi, H.; Ali, K. The Transformation of Tehran from a Garrison Town to a Primate City. In Urban Development in the Muslim World; Routledge: New York, NY, USA, 2018; pp. 109-136.

71. Monthly Report of Mobile Phone Operators. Communications Regulatory Authority (CRA) of The I.R. of Iran. 2020. Available online: https:/ / www.cra.ir/en/enhome (accessed on 1 May 2021).

72. Chin, W.W. The partial least squares approach for structural equation modeling. Mod. Methods Bus. Res. 1998, 295, $295-336$.

73. Fornell, C.; Larcker, D.F. Evaluating Structural Equation Models with Unobservable Variables and Measurement Error. J. Mark. Res. 1981, 18, 39. [CrossRef]

74. Gefen, D.; Straub, D.; Boudreau, M.-C. Structural Equation Modeling and Regression: Guidelines for Research Practice. Commun Assoc. Inf. Syst. 2000, 4, 7. [CrossRef]

75. Petrović, N.; Roblek, V.; Radenković, M.; Nejković, V.; Papachashvili, N. Smart Technologies for the Post-Covid-19 Tourism Industry. In Proceedings of the International Online Conference on Applied Electromagnetics, Niš, Serbia, 30 August-1 September 2021.

76. Dabeedooal, Y.J.; Dindoyal, V.; Allam, Z.; Jones, D.S. Smart Tourism as a Pillar for Sustainable Urban Development: An Alternate Smart City Strategy from Mauritius. Smart Cities 2019, 2, 153-162. [CrossRef]

77. Allam, Z. Global Tourism and the Risks of Cultural Homogeneity in Smart and Future Cities. In The Rise of Autonomous Smart Cities; Springer: Berlin/Heidelberg, Germany, 2021; pp. 75-90.

78. Allam, Z.; Jones, D.S. Pandemic stricken cities on lockdown. Where are our planning and design professionals [now, then and into the future]? Land Use Policy 2020, 97, 104805. [CrossRef]

79. Moreno, C.; Allam, Z.; Chabaud, D.; Gall, C.; Pratlong, F. Introducing the "15-Minute City": Sustainability, Resilience and Place Identity in Future Post-Pandemic Cities. Smart Cities 2021, 4, 93-111. [CrossRef]

80. Allam, Z.; Jones, D.S. Future (post-COVID) digital, smart and sustainable cities in the wake of 6G: Digital twins, immersive realities and new urban economies. Land Use Policy 2021, 101, 105201. [CrossRef]

81. Wang, W.; Kumar, N.; Chen, J.; Gong, Z.; Kong, X.; Wei, W.; Gao, H. Realizing the Potential of the Internet of Things for Smart Tourism with $5 \mathrm{G}$ and AI. IEEE Network 2020, 34, 295-301. [CrossRef]

82. Dickinson, J.E.; Ghali, K.; Cherrett, T.; Speed, C.; Davies, N.; Norgate, S. Tourism and the smartphone app: Capabilities, emerging practice and scope in the travel domain. Curr. Issues Tour. 2014, 17, 84-101. [CrossRef]

83. Camilleri, M.A. Tourism Planning and Destination Marketing; Emerald Publishing: Bingley, UK, 2018 ; ISBN 9781787562912.

84. Camilleri, M.A. Integrated Marketing Communications. In Travel Marketing, Tourism Economics and the Airline Produc; Springer: Berlin/Heidelberg, Germany, 2018. 